\title{
Effects of Copper on Total Phenolics, Flavonoids and Mitochondrial Properties of Orthosiphon stamineus Callus Culture
}

\author{
Dayangku Dalilah Mamat ${ }^{1}$, Chun-Shiong Chong ${ }^{2}$, Azman Abd Samad ${ }^{2}$, Tsun-Thai Chai ${ }^{3,4}$ and Fazilah Abd Manan ${ }^{1^{*}}$ \\ ${ }^{1}$ Department of Biosciences and Health Sciences, Faculty of Biosciences and Medical Engineering, Universiti Teknologi \\ Malaysia, 81310 UTM Johor Bahru, Johor, Malaysia \\ ${ }^{2}$ Department of Biotechnology and Medical Engineering , Faculty of Biosciences and Medical Engineering, Universiti \\ Teknologi Malaysia, 81310 UTM Johor Bahru, Johor, Malaysia \\ ${ }^{3}$ Department of Chemical Science, Faculty of Science, Universiti Tunku Abdul Rahman, 31900 Kampar, Malaysia \\ ${ }^{4}$ Centre for Biodiversity Research, Universiti Tunku Abdul Rahman, 31900 Kampar, Malaysia \\ *For correspondence: fazilah@fbb.utm.my
}

\begin{abstract}
Plants need an appropriate amount of copper to sustain their normal growth. However, excess of copper may interrupt plant development and cause stress. In this study, the responses of Orthosiphon stamineus callus culture under various copper concentrations were investigated. Callus cells at 24-days old were treated with 100, 150, 200 and $250 \mu \mathrm{M}$ of copper solution and harvested after one week. Mitochondria from the calluses were isolated and the total mitochondrial proteins were determined. We used sodium dodecyl sulfate polyacrylamide gel electrophoresis (SDS-PAGE) to compare the mitochondrial protein profiles in normal medium and copper-containing medium. The activities of cytochrome c oxidase, as well as the total phenolic and flavonoid contents were determined. The results of atomic absorption spectroscopy (AAS) analysis have shown significant amount of copper accumulated in $O$. stamineus callus cells, depending on the amount of copper supplied. With the BCF values of more than 10, this species can be categorized as copper hyperaccumulator. When the amount of copper supplied increased, the cells exhibit higher cytochrome c oxidase activities and produce more phenolic compounds, in spite of decreasing amount of total mitochondrial proteins and a lesser number of visible bands visualized from SDS-PAGE analysis. Overall, our findings highlight the dynamic responses of $O$. stamineus cells when exposed to various levels of copper, notably by alteration of biochemical and mitochondrial properties as their protection mechanism under stress. (C) 2015 Friends Science Publishers
\end{abstract}

Keywords: Heavy metals; Plant mitochondria; Cultured cells; Orthosiphon stamineus

\section{Introduction}

Copper is one of the most important micronutrients in plants. In general, it is required as a cofactor for many enzymes involve in respiration, photosynthesis and protein metabolisms (Yruela, 2005). However, high level of copper will lead to toxicity and disturb the normal processes in plant tissues, cells, and organelles including mitochondria (Keunen et al., 2011; Rahman et al., 2013).

Mitochondria in plants have various roles, especially in the generation of energy (Hanson and Day, 2013). Mitochondrial proteins are mostly encoded by plant nuclear genome, while the mitochondrial genome encodes a few components of the ETC (electron transport chain) (Cooper, 2000). During respiration, proteins involved in the primary metabolic reactions in tricarboxylic acid cycle are catalyzed by copper and iron; thus, facilitate the electron transfer in ETC (Xu et al., 2013; Garcia et al., 2014). Hence, appropriate amount of copper is essential for proper mitochondrial functions and whole plant development.

Nowadays, environmental pollution due to excess of heavy metals has become a serious issue. Copper contamination in soil and water bodies may come from natural and anthropogenic activities such as agriculture, mining, and metallurgical industries (He et al., 2005; Nagajyoti et al., 2010). As adaptive measures towards copper stress, plants may change their physiological and biochemical properties to continue survival. If plants are tolerant to the metal, they can be used for phytoremediation purposes. However, this will depend on plant individual capacity and the amount of metals present in their surroundings.

To date, studies related to mitochondria from the callus culture have not been widely reported. Previously, the streptomycin resistance of tobacco cultured cells and the response of mitochondria from calluses-forming potato 
tuber disks towards ethanol and growth temperature were reported (Plas and Wagner, 1980; Hemrika-Wagner et al., 1982; Zamski and Umiel, 1982). Quite recently, the effects of nitric oxidase to mitochondrial respiration of Arabidopsis thaliana calluses were investigated (Wang et al., 2010). Hence, the information on mitochondrial response of the cultured cells under stress is limited.

This study attempted to better understand the biochemical and mitochondrial properties of Orthosiphon stamineus calluses when exposed to copper stress. $O$. stamineus is a type of medicinal herb widely found in Malaysia. The leaves extract of this plant is known to possess strong antioxidant capacity (Akowuah et al., 2004). In specific, the objectives of this study were to explore the responses of $O$. stamineus cultured cells in terms of copper accumulation level, and the production of phenolics and flavonoid compounds, besides profiling the mitochondrial properties subsequent to its mitochondrial isolation. Overall, this study will enable us to assess the capacity of this species to be used in copper remediation.

\section{Materials and Methods}

\section{Plant Materials}

Misai Kucing (O. stamineus) aged 3 weeks old were purchased from a local supplier in Johor, Malaysia. Plants were placed in the glasshouse, watered twice per day with tap water early in the morning and late in the evening. The day length is $12-\mathrm{h}$, similar to the night length. The range of daily temperature is $26^{\circ} \mathrm{C}$ to $33^{\circ} \mathrm{C}$ and the relative humidity is above $80 \%$.

\section{Callus Development and Surface Sterilization}

Matured leaf explants were selected from O. stamineus plants and smeared in commercial liquid soap prior to the washing step under running tap water for $30 \mathrm{~min}$. Whole leaves were placed in sterilized jars and ethanol $70 \%(\mathrm{v} / \mathrm{v})$ were applied for one minute. $20 \%$ of bleach solution was used for 30 min with an addition of a few drops of Tween 20 , followed by three times rinse with sterile distilled water. Plant leaves were cut with sterilized cutter blade to establish $1 \mathrm{~cm} \times 1 \mathrm{~cm}$ square shape each. Five pieces of cut leaves were cultured into each Petri dish containing agar MS medium plus NAA $1 \mathrm{mg} / \mathrm{L}$ and 2,4-D $1 \mathrm{mg} / \mathrm{L}$ for callus induction. Callus of $O$. stamineus were established until maturation by day- 24 .

\section{Treatment of Callus Culture}

The callus culture placed in jars, each containing MS medium containing $1 \mathrm{mg} / \mathrm{L} \mathrm{NAA}$ and $1 \mathrm{mg} / \mathrm{L} \mathrm{2,} \mathrm{4-D} \mathrm{with}$ different concentration of $\mathrm{CuSO}_{4} .5 \mathrm{H}_{2} \mathrm{O}$. The treatments were indicated as $\mathrm{T} 1=\mathrm{control}, \mathrm{T} 2=100 \mu \mathrm{M}, \mathrm{T} 3=150 \mu \mathrm{M}$, $\mathrm{T} 4=200 \mu \mathrm{M}, \mathrm{T} 5=250 \mu \mathrm{M}$. Calluses were harvested after one week of $\mathrm{CuSO}_{4} .5 \mathrm{H}_{2} \mathrm{O}$ treatments.

\section{Determination of Heavy Metal Content}

Prior to heavy metal analysis, callus samples were dried in the oven at $80^{\circ} \mathrm{C}$ for $72 \mathrm{~h}$. Dried samples were pulverized into powder and approximately $0.1 \mathrm{~g}$ samples were subjected to acid digestion process. Nitric acids followed by perchloric acid $(2: 1)$ were added to the powdered samples. Digested sample was further diluted and aliquots were used for estimation of copper concentration. The measurements of these metal elements were conducted using Atomic Absorption Spectrophotometer (AAS) Model AAnalyst 400 (Perkin Elmer, Massachusetts, USA). Sample preparation and heavy metal analysis were conducted based on the standard method by the American Public Health Association (APHA-AWWA-WPCF, 1980).

\section{Heavy Metal Analysis}

The accumulations of copper in $O$. stamineus was calculated using bio-concentration factor $(\mathrm{BCF})$ as follows: $\mathrm{BCF}=$ metal concentration in callus/metal concentration in medium.

\section{Mitochondrial Isolation}

Mitochondria were isolated using a method from (Wilson and Chourey, 1984) with some modifications. Callus tissues were grounded in a pre-chilled mortar and pestle which consisted of $10 \mathrm{mM}$ n-tris (hydroxymethyl)methyl-2aminoethane-sulphonic acid (TES), pH 7.2, 0.5 M mannitol, $1 \mathrm{mM}$ ethylene glycol-bis-(2-aminoethylether)-n, n'tetraacetic acid (EGTA), $0.2 \% \mathrm{w} / \mathrm{v}$ BSA, and $0.05 \% \mathrm{w} / \mathrm{v}$ cysteine. After that, the suspension was filtered through 4 layers of cheesecloth into pre-chilled tubes. Using a fresh buffer, the tissues were re-grounded two more times and the pooled filtrate was centrifuged at $1000 \mathrm{x} \mathrm{g}$ for $10 \mathrm{~min}$ at $4^{\circ} \mathrm{C}$. Next, mitochondria were collected from the supernatant by centrifugation at $16,000 \times \mathrm{g}$ for $10 \mathrm{~min}$ at $4^{\circ} \mathrm{C}$. A small paint brush was used to resuspend the mitochondrial pellet in a 10 $\mathrm{mL}$ pre-chilled buffer that consisted of $0.3 \mathrm{M}$ sucrose and $0.05 \mathrm{M}$ Tris, $\mathrm{pH}$ 7. The mitochondria were pelleted by centrifugation at $12,000 \mathrm{x} \mathrm{g}$ for $20 \mathrm{~min}$ at $4{ }^{\circ} \mathrm{C}$. The mitochondrial pellet was resuspend in a $10 \mathrm{~mL}$ buffer and re-pelleted at $14,000 \mathrm{x} \mathrm{g}$ for $10 \mathrm{~min}$ at $4^{\circ} \mathrm{C}$. Next, the pellet was resuspend in a $10 \mathrm{~mL}$ sucrose wash buffer and stored in $-80^{\circ} \mathrm{C}$ freezer prior to usage.

\section{Mitochondrial Protein Quantification}

The protein concentrations of isolated mitochondria were determined using Optiblot Bradford Reagent (Abcam, USA). A standard for protein was prepared from BSA $(1 \mathrm{mg} / \mathrm{mL})$. Sample $(20 \mu \mathrm{L})$ and $300 \mu \mathrm{L}$ reagent were mixed and absorbance at $595 \mathrm{~nm}$ was recorded (Bradford, 1976). 


\section{Mitochondrial Cytochrome C Oxidase Test}

The activity of cytochrome c oxidase in isolated mitochondria was determined using Cytochrome c Oxidase Assay Kit (Sigma-Aldrich, USA) based on the instruction recommended by the manufacturer. This colorimetric assay is based on an observation of the decrease in absorbance at $550 \mathrm{~nm}$ of ferrocytochrome c caused by its oxidation to ferricytochrome $\mathrm{c}$ by cytochrome c oxidase.

\section{Sodium Dodecyl Sulfate - Polyacrylamide Gel Electrophoresis SDS-PAGE}

SDS-PAGE was carried out based on (Bollag et al., 1996). The stacking gel solution (125 mM Trishydrochloride (Tris$\mathrm{HCl}) \mathrm{pH} 6.8,0.1 \%(\mathrm{w} / \mathrm{v})$ SDS, 5\% (w/v) acrylamide (acrylamide: bis-acrylamide ratio of 37.5: 1), 0.07\% (w/v) ammonium persulphate and $0.03 \%(\mathrm{v} / \mathrm{v}) \quad \mathrm{N}, \mathrm{N}, \mathrm{N}^{\prime}, \mathrm{N}^{\prime}-$ tetramethylethane-1,2-diamine (TEMED) was overlaid on the separating gel solution $(373 \mathrm{mM}$ Tris- $\mathrm{HCl} \mathrm{pH} 8.8,0.1 \%$ $(\mathrm{w} / \mathrm{v})$ SDS, $12 \%(\mathrm{w} / \mathrm{v})$ acrylamide, $0.04 \%(\mathrm{w} / \mathrm{v})$ ammonium persulphate and $0.05 \%$ (v/v) TEMED). Samples were mixed with $5 \mathrm{X}$ sample buffer $(60 \mathrm{mM}$ Tris-HCl, $\mathrm{pH} 6.8,2 \%$ (w/v) SDS, 25\% (v/v) glycerol, $0.1 \%(\mathrm{w} / \mathrm{v})$ bromophenol blue, $14.4 \mathrm{mM} 2$-mercaptoethanol) and heated for $5 \mathrm{~min}$ at $90^{\circ} \mathrm{C}$, followed by centrifugation at $10,000 \mathrm{xg}$ for $5 \mathrm{~min}$ at $25^{\circ} \mathrm{C}$. The same amount of protein samples was loaded on the gel and separated at $150 \mathrm{~V}$ until the bromophenol blue reached the bottom of the gel. The gel was stained with Coomassie Blue: The gel was incubated in Coomassie blue R-250 (0.1\% (w/v) coomassie blue R-250, 10\% (v/v) acetic acid, 45\% $(\mathrm{v} / \mathrm{v})$ methanol) for $16 \mathrm{~h}$ and transferred to destaining solution $(10 \%(\mathrm{v} / \mathrm{v})$ methanol, $10 \%(\mathrm{v} / \mathrm{v})$ acetic acid). The gel was destained until the protein bands are visible and the image was then captured.

\section{Aqueous Extracts Preparation}

Dried samples were pulverized using mortar and pestle and extracted with autoclaved deionized water at the ratio of 1:40 (dry weight: volume), at $90^{\circ} \mathrm{C}$ for $1 \mathrm{~h}$. The heat incubated homogenate was vacuum-filtered and the filtrate was centrifuged at $9000 \mathrm{rpm}$ at $4^{\circ} \mathrm{C}$ for $15 \mathrm{~min}$. The supernatant obtained was immediately aliquoted $(500 \mu \mathrm{L}$ each) and stored at $-20^{\circ} \mathrm{C}$ prior to analysis.

\section{Determination of Total Phenolic Content}

Determination of total phenolic contents in the extracts was conducted using a Folin-Ciocalteu colorimetric assay (Waterhouse, 2001). A mixture containing extract $(0.2 \mathrm{~mL})$, deionized water $(0.8 \mathrm{~mL})$, and Folin Ciocalteu reagent $(0.1$ $\mathrm{mL}$ ) was incubated at room temperature for $3 \mathrm{~min}$. Next, $0.3 \mathrm{~mL}$ of $\mathrm{Na}_{2} \mathrm{CO}_{3}(20 \% \mathrm{w} / \mathrm{v})$ was added and the mixture was incubated at room temperature for $120 \mathrm{~min}$.
Absorbance of the mixture was recorded at $765 \mathrm{~nm}$. A standard curve was prepared from 0 to $100 \mathrm{mg} / \mathrm{L}$ gallic acid. Total phenolic content was expressed in $\mathrm{mg}$ gallic acid equivalents/g dry matter.

\section{Determination of Total Flavonoid Content}

The content of flavonoids in the extracts was determined as previously described (Zou et al., 2004). Plant extract (0.2 $\mathrm{mL})$ was added to $0.15 \mathrm{~mL}$ of $\mathrm{NaNO}_{2}(5 \% \mathrm{w} / \mathrm{v})$ and the mixture was incubated at room temperature for $6 \mathrm{~min}$. Then, $0.15 \mathrm{~mL}$ of $\mathrm{AlCl}_{3} \cdot 6 \mathrm{H}_{2} \mathrm{O}(10 \% \mathrm{w} / \mathrm{v})$ was added to the mixture and incubated for $6 \mathrm{~min}$ at room temperature, followed by an addition of $0.8 \mathrm{~mL}$ of $\mathrm{NaOH}(10 \% \mathrm{w} / \mathrm{v})$. The mixture was incubated at room temperature for $15 \mathrm{~min}$. and absorbance of the mixture was recorded at $510 \mathrm{~nm}$. A standard curve was prepared from 0 to $500 \mu \mathrm{g} / \mathrm{mL}$ quercetin dissolved in $80 \%$ ethanol and total flavonoid content was expressed in $\mathrm{mg}$ quercetin equivalents/g dry matter.

\section{Data Analysis}

Experiments were carried out in triplicates. Data were analyzed using Microsoft Excel 2007 and reported as mean \pm standard error. Tukey's test was used at the 0.05 level of probability for comparison of the set of means.

\section{Results}

\section{Orthosiphon stamineus Calluses Have the Capacity to Accumulate Copper}

The concentrations of copper in $O$. stamineus callus cells were increased as the concentrations of copper supplied increased. Although the magnitude of the $\mathrm{BCF}$ varied with the concentration of copper supplied in media, the $\mathrm{BCF}$ values of more than 10 indicate good copperhyperaccumulation properties in O. stamineus (Table 1). The highest BCF of 12, was determined from calluses in mediums containing $200 \mu \mathrm{M}$ and $250 \mu \mathrm{M}$ of copper.

\section{Copper Stress Reduced the Total Mitochondrial Protein Content in O. stamineus Calluses}

Callus cells contain mitochondria although the density was lower than the differentiated cells. The results from our analysis showed a significantly lower amount of mitochondrial proteins in the callus exposed to copper treatments compared to control (Table 2). The concentrations of mitochondrial protein were 1.1, 1.3, 1.4, and 1.3-fold lesser than the control for 100, 150, 200 and $250 \mu \mathrm{M}$ copper treatments, respectively. A similar trend for the yield of protein in isolated mitochondria was observed (Table 2). Comparisons between different copper treatments also exhibit significant differences in mitochondrial proteins contents and yield, except between the treatments using 150 
Table 1: Concentrations of copper in $O$. stamineus callus and the bioconcentration factor

\begin{tabular}{lll}
\hline $\begin{array}{l}\text { Level of Cu supplied in } \\
\text { medium }(\mu \mathrm{M})\end{array}$ & $\begin{array}{l}\text { Level of Cu in callus } \\
(\mu \mathrm{M})\end{array}$ & $\begin{array}{l}\text { Bioconcentration } \\
\text { factor }(\mathrm{BCF})\end{array}$ \\
\hline Control & $0^{\mathrm{a}}$ & 0 \\
100 & $1115.83 \pm 5.40^{\mathrm{b}}$ & 11.2 \\
150 & $1522.04 \pm 29.11^{\mathrm{c}}$ & 10.1 \\
200 & $2445.79 \pm 10.10^{\mathrm{d}}$ & 12.2 \\
250 & $3017.73 \pm 13.53^{\mathrm{e}}$ & 12.1 \\
\hline
\end{tabular}

Data are means \pm standard errors $(n=3)$. Different lowercase letters indicate significant differences among treatments within a column according to Tukey's Test $(\mathrm{p}<0.05)$

Table 2: Mitochondrial protein concentrations and yield from $O$. stamineus callus grown in different copper treatments

\begin{tabular}{lll}
\hline Copper treatment $(\mu \mathrm{M})$ & Protein concentrations $(\mathrm{mg} / \mathrm{ml})$ & Yield $(\mathrm{mg})$ \\
\hline Control & $16.86 \pm 0.18^{\mathrm{a}}$ & $168.60 \pm 1.78^{\mathrm{a}}$ \\
100 & $15.70 \pm 0.12^{\mathrm{b}}$ & $157.04 \pm 1.17^{\mathrm{b}}$ \\
150 & $12.58 \pm 0.33^{\mathrm{c}}$ & $125.78 \pm 3.26^{\mathrm{c}}$ \\
200 & $12.33 \pm 0.03^{\mathrm{dc}}$ & $123.26 \pm 0.32^{\mathrm{dc}}$ \\
250 & $13.26 \pm 0.06^{\mathrm{e}}$ & $132.58 \pm 0.59^{\mathrm{e}}$ \\
\hline Data are means \pm standard errors $(\mathrm{n}=3)$. Different lowercase letters \\
indicate significant differences among treatments within a column \\
according to Tukey's Test $(\mathrm{p}<0.05)$
\end{tabular}

Table 3: Total phenolic and flavonoid contents in the callus of $O$. stamineus

\begin{tabular}{lll}
\hline Parameter & Total phenolics (mg GAE/g) & Total flavonoids (mg Quercetin/g) \\
\hline Control & $167.30 \pm 0.25^{\mathrm{a}}$ & $9.18 \pm 0.17^{\mathrm{a}}$ \\
$100 \mu \mathrm{M}$ & $169.88 \pm 2.02^{\mathrm{ab}}$ & $9.64 \pm 0.11^{\mathrm{a}}$ \\
$150 \mu \mathrm{M}$ & $171.62 \pm 0.16^{\mathrm{ab}}$ & $9.38 \pm 0.18^{\mathrm{a}}$ \\
$200 \mu \mathrm{M}$ & $175.94 \pm 2.98^{\mathrm{b}}$ & $9.47 \pm 0.07^{\mathrm{a}}$ \\
$250 \mu \mathrm{M}$ & $172.25 \pm 0.61^{\mathrm{ab}}$ & $9.44 \pm 0.06^{\mathrm{a}}$ \\
\hline
\end{tabular}

Data are means \pm standard errors $(n=3)$. Different lowercase letters indicate significant differences among treatments within a column according to Tukey's Test $(\mathrm{p}<0.05)$

and $200 \mu \mathrm{M}$ of copper solution.

\section{Copper Treatment Increased the Activity of Mitochondrial Cyt C Oxidase}

Our results revealed that the activity of cytochrome c oxidase has been increased with increasing amount of copper, in spite of the reduction of total mitochondrial protein contents. The detection of cytochrome c oxidase activity signified the success of our mitochondrial isolation. We demonstrated that the activity of cytochrome $\mathrm{c}$ oxidase increased significantly at 5.3-fold when treated with 200 $\mu \mathrm{M}$ copper, while at the highest copper treatment $(250 \mu \mathrm{M})$, the cytochrome $\mathrm{c}$ oxidase activity was 11.3 -fold higher compared to control (Fig. 1).

\section{The Profile of Mitochondrial Protein from $O$. stamineus Calluses}

The protein profiles of mitochondria from $O$. stamineus calluses were obtained from SDS-PAGE. The results showed that the protein bands were more visible in the control, compared to samples treated with copper. There were three clear protein bands in the control treatments with molecular weight slightly less than $75 \mathrm{kDa}$, approximately $50 \mathrm{kDa}$, and $25 \mathrm{kDa}$. The former band intensity increased with copper treatment. However, the intensity of $\sim 50 \mathrm{kDa}$ and $\sim 25 \mathrm{kDa}$ protein bands decreased with copper treatments (Fig. 2).

\section{Total Phenolic Contents Increased in Copper Treated $O$. stamineus Calluses}

Analysis of ethanol extracts of $O$. stamineus with different amount of copper showed significantly 5.2\% higher amount of total phenolic content in the callus treated with $200 \mu \mathrm{M}$ copper, compared to control. Although there was a slight reduction in total phenolics content when cells were exposed to $250 \mu \mathrm{M}$ copper, this change was not significantly different when compared to other treatments. The total flavonoid however, did not differ significantly between all treatments (Table 3).

\section{Discussion}

Understanding the response of plants under stress is important to evaluate plant capacity to be used in bioremediation. Generally, the BCF value is one of the indicators for plant capacity to accumulate or tolerate heavy metals. The BCF values of 1 to 10 indicate the plant ability as hyperaccumulator (Audet and Charest, 2007). High BCF values for $O$. stamineus calluses showed good copperhyperaccumulation properties. Our result was in agreement with a previous report on the ability of $O$. stamineus whole plants to absorb heavy metals (Abdu et al., 2011), and further proved that plants in Lamiacea family are potential metal accumulators as reported by (Saxena and Misra 2010). Earlier, heavy metal tolerance in the cultured cells has been demonstrated in their respective intact plants, for instance in Anthoxantum odoratum (Qureshi et al., 1981). However, unlike the intact plants, the mechanisms of heavy metal tolerance in callus cells are not fully elucidated, especially in relation to plant mitochondrial properties. Nevertheless, it is known that metal stress triggers the production of antioxidant, which acts a defense mechanism in callus cells (Gallego et al., 2002; Xu et al., 2011; Lukatkin et al., 2014).

Different amount of protein content in plants during stress is an indicator for alteration in plant metabolisms. Our study revealed the decreased level of mitochondrial protein concentrations and yield with increasing amount of copper treatment. Previously, reductions of total protein content in plants due to copper stress have been reported, although they were highly depending on the duration of exposure (Zengin and Kirbag, 2007; Vinod et al., 2012; Brahim and Mohamed, 2013). While those studies focused on total proteins, our research is focusing on mitochondrial 


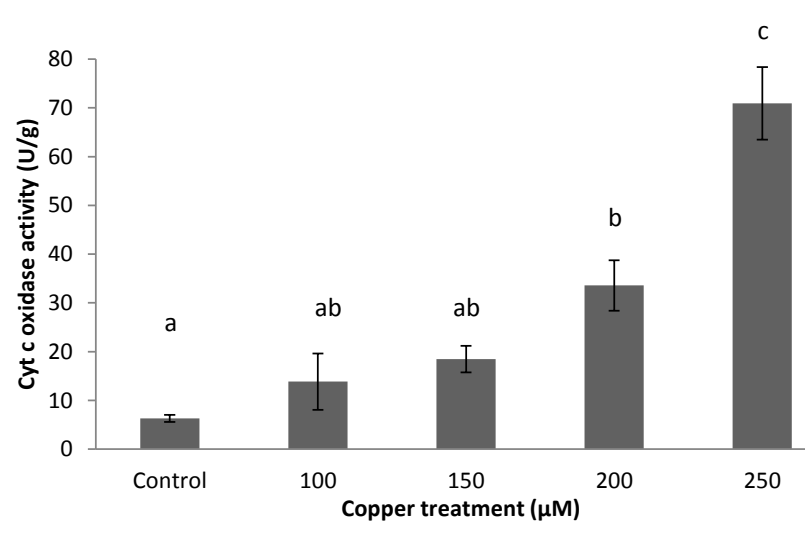

Fig. 1: Cytochrome c oxidase activity in Orthosiphon stamineus callus grown in different copper concentrations. Data are means \pm standard errors $(n=3)$. Different lowercase letters indicate significant differences among treatments within a column according to Tukey's Test $(\mathrm{p}<0.05)$

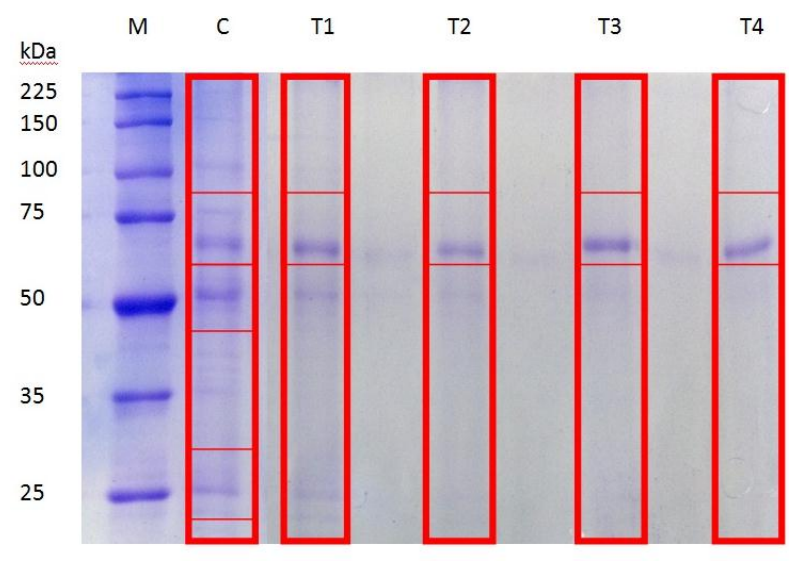

Fig. 2: Protein expression profiles of mitochondrial proteins from Orthosiphon stamineus treated with different concentrations of $\mathrm{Cu} . \mathrm{M}=$ Molecular weight protein marker $\mathrm{kDa}$. $\mathrm{C}=$ Control. $\mathrm{T} 1=100 \mu \mathrm{M} \mathrm{Cu}$. T2 $=150 \mu \mathrm{M} \mathrm{Cu}$. T3= $200 \mu \mathrm{M} \mathrm{Cu}$. T4=250 $\mu \mathrm{M} \mathrm{Cu}$

proteins. Proteins in plant mitochondria are complex with up to 3000 gene products (Millar et al., 2007). These proteins are involved in various functions such as respiration transport, stress response, and many more (Zeng et al., 2007). It was previously reported that high level of copper inhibits plant respiration and induces the production of alternative oxidases in cultured cells (Padua et al., 1999). In this study, we detected a much lesser amount of total mitochondrial proteins under copper stress, indicating that certain processes in mitochondria may be compromised.

The activity of cytochrome c oxidase, an important enzyme in mitochondrial ETC, increased when higher amount of copper is applied. Generally, copper toxicity causes oxidative stress and possibly leads to dysfunction of cytochrome c (Srinivasan and Avadhani, 2012). However, in our case, excess of copper may promote the activity of cytochrome $\mathrm{c}$ oxidase that naturally requires copper as a cofactor and functions as its terminal electron acceptor (Pilon et al., 2006).

Then, we further analyzed the protein profiles from SDS-PAGE and observed differential expressions of polypeptides during metal stress. We predict that some mitochondrial proteins might have small molecular weight, thus, the bands are invisible on the gel. Based on molecular weight, the protein band with decreased intensity is most probably the heat shock protein-60 (HSP-60) or known as chaperonin 60. This is a mitochondrial chaperonin accountable in transportation and protein refolding from the cytoplasm into the mitochondrial matrix (Deocaris et al., 2006). Earlier works on human mitochondria also revealed the expression of HSP 60, as well as several other proteins when exposed to copper ions (Choi et al., 2012).

Since mitochondria are very synonym with reactive oxygen species, we determined the total phenolic and flavonoid content in our samples. The phenolic and flavonoid are secondary antioxidant compounds normally produced by plants to defend themselves under stress condition by chelating the metals that interfere normal plant processes (Michalak, 2006), as well as inhibit ROS generation (Deng et al., 1997; Grael et al., 2010). Although there was a significant increase in total phenolic content with increasing copper concentrations, the percentage of increment seems low, probably due to low level of oxidative stress in cells.

\section{Conclusion}

The findings described in this paper show that $O$. stamineus calluses react dynamically toward copper stress. The callus absorbed a significant amount of copper from the medium, hence, categorized as hyperaccumulator. The active response of callus to stress has been shown by the increasing amount of total phenolic compounds and higher activities of cytochrome $\mathrm{c}$ oxidase. In addition, changes in the total mitochondrial protein content and different intensity of several bands with respect to copper amount may reflect the reaction of these cells under stress. It also proved that mitochondria are important organelles in plants that function synergistically with other components in the cells for normal plant growth and development. Taken together, since $O$. stamineus species has high potential in surviving copper stress, we suggest that this species might potentially be used as phytoremediation agent in the future.

\section{Acknowledgement}

We would like to thank Universiti Teknologi Malaysia (UTM) and the Ministry of Education, Malaysia for providing Fundamental Research Grant Scheme for this study (7845.4F180). 


\section{References}

Abdu, A., N. Aderis, H. Abdul-Hamid, N.M. Majid, S. Jusop, D.S. Karam and K. Ahmad, 2011. Using Orthosiphon stamineus B. for Phytoremediation of Heavy Metals in Soils Amended with Sewage Sludge. Amer. J. Appl. Sci., 8: 323-331

Akowuah, G.A., I. Zhari, I. Norhayati, A. Sadikun and S.M. Khamsah, 2004. Sinensetin, eupatorin, 3'-hydroxy-5, 6, 7, 4'-tetramethoxyflavone and rosmarinic acid contents and antioxidative effect of Orthosiphon stamineus from Malaysia. Food Chem., 4: 559-566

APHA-AWWA-WPCF (American Public Health Association, American Water Works Association and Water Pollution Control Federation), 1980. In: Standard Methods for the Examination of Water and Wastewater, $15^{\text {th }}$ edition, pp: 141-147. American Public Health Association, NW Washington DC, USA

Audet, P. and C. Charest, 2007. Heavy metal phytoremediation from a meta-analytical perspective. Environ. Pollut., 147: 231-237

Bollag, D.M., M.D. Rozycki and S.J. Edelstein, 1996. Protein Methods. Gel Electroporesis under denaturing conditions, Second Edition, WileyLiss, New York, USA

Bradford, M.M., 1976. A rapid and sensitive method for the quantitation of microgram quantities of protein utilizing the principle of protein-dye binding. Anal. Biochem., 72: 248-254

Brahim, L. and M. Mohamed, 2013. Effects of copper stress on antioxidative enzymes, chlorophyll and protein content in Atriplex halimus. Afr. J. Biotechnol., 10: 10143-10148

Choi, M.R., K.H. Jung, H.T. Lee, J.H. Park, T. Ohn and Y.G. Chai, 2012. Proteomic analysis of the copper ion-induced stress response in a human embryonic carcinoma cell line. Int. J. Toxicol., 31: 397-406

Cooper, G.M., 2000. The Cell: A Molecular Approach, $2^{\text {nd }}$ edition Sunderland (MA): Sinauer Associates. Mitochondria. Available at: http://www.ncbi.nlm.nih.gov/books/NBK9896/(Accessed: 1 October 2014)

Deng, W., X. Fang and J. Wu, 1997. Flavonoids function as antioxidants: by scavenging reactive oxygen species or by chelating iron? Rad. Phys. Chem., 50: 271-276

Deocaris, C.C., S.C. Kaul and R. Wadhwa, 2006. On the brotherhood of the mitochondrial chaperones mortalin and heat shock protein 60. Cell Stress Chaperones, 11: 116-128

Gallego, S.M., M.P. Benavides and M.L. Tomaro, 2002. Involvement of antioxidant defense system in the adaptive response to heavy metal ions in Helianthus annuus L. cells. Plant Growth Regul., 36: 17-21

Garcia, L., E. Welchen and D.H. Gonzalez, 2014. Mitochondria and copper homeostasis in plants. Mitochondrion, 19: 269-274

Grael, C.F.F., A. Kanashiro, L.M. Kabeya, C.O. Jordao, R. Takeara, L. Gobbo-Neto, A.C.M. Polizello, Y.M. Lucisano-Valim, N.P. Lopes and J.L.C. Lopes, 2010. In vitro study of antioxidant and scavenger properties of phenolic compounds from Lychnophora species. Química Nova., 33: 867-870

Hanson, J.B. and D.A. Day, 2013. Plant mitochondria. Biochem. Plants, 1: $315-358$

He, Z.L., X.E. Yang and P.J. Stoffella, 2005. Trace elements in agroecosystems and impacts on the environment. J. Trace Elem. Med. Biol., 19: 125-140

Hemrika-Wagner, A.M., K.C. Kreuk and L.H. van der Plas, 1982. Influence of growth temperature on respiratory characteristics of mitochondria from callus-forming potato tuber discs. Plant Physiol., 70: 602-605

Keunen, E., T. Remans, S. Bohler, J. Vangronsveld and A. Cuypers, 2011. Metal-induced oxidative stress and plant mitochondria. Int. J. Mol. Sci., 12: 6894-6918

Lukatkin,A., I.Egorova, I. Michailova, P. Malec and K. Strzałka, 2014. Effect of copper on pro-and antioxidative reactions in radish (Raphanus sativus L.) in vitro and in vivo. J. Trace Elem. Med. Biol., 28: 80-86
Michalak, A., 2006. Phenolic compounds and their antioxidant activity in plants growing under heavy metal stress. Polish J. Environ. Stud., 15: 523-530

Millar, A.H., 2007. The plant mitochondrial proteome. In: Plant Proteomics, pp: 226-246. Springer Berlin Heidelberg, Germany

Nagajyoti, P.C., K.D. Lee and T.V.M. Sreekanth, 2010. Heavy metals, occurrence and toxicity for plants: a review. Environ. Chem. Lett., 8: 199-216

Padua, M., S. Aubert, A. Casimiro, R. Bligny, A.H. Millar and D.A. Day, 1999. Induction of alternative oxidase by excess copper in sycamore cell suspensions. Plant Physiol. Biochem., 37: 131-137

Pilon, M., S.E. Abdel-Ghany, C.M. Cohu, K.A. Gogolin, and H. Ye, 2006. Copper cofactor delivery in plant cells. Curr Opin. Plant Biol., 9: 256-263

Plas, L.H. and M.J. Wagner, 1980. Influence of ethanol on alternative oxidase in mitochondria from callus-forming potato tuber discs. Physiol. Plant.., 49: 121-126

Qureshi, J.A., H.A. Collin, K. Hardwick and D.A. Thurman, 1981. Metal tolerance in tissue cultures of Anthoxanthum odoratum. Plant Cell Rep., 1: 80-82

Rahman, M.M., P.J. Tan, G. Faruq, A.M. Sofian, H. Rosli and A.N. Boyce, 2013. Use of amaranth (Amaranthus paniculatus) and Indian mustard (Brassica juncea) for phytoextraction of lead and copper from contaminated soil. Int. J. Agric. Biol., 15: 903-908

Saxena, P. and N. Misra, 2010. Remediation of heavy metal contaminated tropical land. In: Soil Heavy Metals, pp: 431-477. Springer Berlin Heidelberg, Germany

Srinivasan, S. and N.G. Avadhani, 2012. Cytochrome c oxidase dysfunction in oxidative stress. Free Rad. Biol. Med., 53: 1252-1263

Vinod, K., G. Awasthi and P.K. Chauhan, 2012. $\mathrm{Cu}$ and $\mathrm{Zn}$ tolerance and responses of the Biochemical and Physiochemical system of Wheat. J. Stress Physiol. Biochem., 8: 203-213

Wang, X., J. Li, J. Liu, W. He and Y. Bi, 2010. Nitric oxide increases mitochondrial respiration in a cGMP-dependent manner in the callus from Arabidopsis thaliana. Nitric Oxide., 23: 242-250

Waterhouse, A.L. 2001. Determination of total phenolics. In: Current Protocols in Food Analytical Chemistry, pp: I1.1.1-I1.1.8. Wrolstad, E.R.E. (ed.). John Wiley and Sons, Inc., New York, USA

Wilson, A.J. and P.S. Chourey, 1984. A rapid inexpensive method for the isolation of restrictable mitochondrial DNA from various plant sources. Plant Cell Rep., 3: 237-239

Xu, X.Y., G.X. Shi, J. Wang and Y.N. Kang, 2011. Copper-induced oxidative stress in Alternanthera philoxeroides callus. Plant Cell, Tiss. Organ Cult., 106: 243-251

$\mathrm{Xu}, \mathrm{W} ., \mathrm{T}$. Barrientos and N.C. Andrews, 2013. Iron and copper in mitochondrial diseases. Cell Metab., 17: 319-32

Yruela, I., 2005. Copper in plants. Braz. J. Plant Physiol., 17: 145-156

Zamski, E. and N. Umiel, 1982. Streptomycin Resistance in Tobacco: IV. Effects of the Drug on the Ultrastructure of Plastids and Mitochondria in Cotyledons of Germinating Seeds. Z Pflanzenphysiol., 105: 143-148

Zeng, H., J.T. Saari and W.T. Johnson, 2007. Copper deficiency decreases complex IV but not complex I, II, III, or V in the mitochondrial respiratory chain in rat heart. J. Nutr., 137: 14-18

Zengin, F.K. and S. Kirbag, 2007. Effects of copper on chlorophyll, proline, protein and abscisic acid level of sunflower (Helianthus anпииs L.) seedlings. J. Environ. Biol., 28: 561-566

Zou, Y., Y. Lu and D. Wei, 2004. Antioxidant activity of a flavonoid-rich extract of Hypericum perforatum L. in vitro. J. Agric. Food Chem., 52: 5032-5039

(Received 27 October 2014; Accepted 16 April 2015) 